\title{
INOVASI TEKNOLOGI DALAM MENINGKATKAN DAYA SAING PRODUK TERASI PUGER
}

\author{
TECHNOLOGICAL INNOVATIONS IN INCREASING THE \\ COMPETITIVENESS OF PUGER SHRIMP PASTE PRODUCTS
}

\author{
Ida Adha Anrosana ${ }^{1)}$, Linda Eka Dewi Widyatami ${ }^{2}$, Guntur Pribadi ${ }^{3)}$, Oktanita \\ Jaya Anggraeni ${ }^{4}$, Amar Subagiyo ${ }^{5)}$ \\ 1,2,3,4,5 Jurusan Manajemen Agribisnis, Politeknik Negeri Jember \\ ${ }^{1}$ Email: ida_adha@polije.ac.id
}

\begin{abstract}
Abstrak: Pelaksanaan kegiatan pengabdian kepada masyarakat di sentra industri terasi Puger berawal dari permintaan bantuan teknologi yang berkaitan dengan pengolahan terasi dan manajemen bisnis dari pengusaha terasi Puger di Desa Puger Kulon Kecamatan Puger Kabupaten Jember. Permasalahan utama yang dikemukakan pengusaha terasi Puger adalah kapasitas produksi yang rendah, volume penjualan yang tidak mengalami peningkatan dan pemasaran produk yang terbatas. Kegiatan ini bertujuan mengatasi permasalahan yang dihadapi mitra dengan menawarkan suatu inovasi berupa modifikasi alat pengolah terasi ramah lingkungan, kapasitas produksi tinggi dan higienis serta memberikan pelatihan manajemen bisnis untuk meningkatkan usaha yang telah dilakukan. Metode yang dilakukan antara lain melalui demonstrasi alat, dan pelatihan pada mitra serta layanan jasa konsultasi. Hasil kegiatan ini berupa penerapan mesin pengolah terasi modern untuk meningkatkan kapasitas produksi, penggunaan pembukan sederhana untuk industri menengah, pengemasan produk terasi berbagai ukuran dengan bahan pengemas yang aman, estetik dan ergonomis.
\end{abstract}

Kata Kunci: Inovasi teknologi, Terasi puger

\begin{abstract}
The implementation of community service activities at the puger shrimp paste industry center began with requests for technology assistance related to shrimp paste processing and business management from puger shrimp paste entrepreneurs in Puger Kulon Village, Puger District, Jember Regency. The main problems raised by the puger shrimp paste entrepreneur are low production capacity, unimproved sales volume and limited product marketing. This activity aims to overcome the problems faced by partners by offering an innovation in the form of modification of an environmentally friendly shrimp paste processing tool, high production capacity and hygienic as well as providing business management training to improve the business that has been done. The methods used include demonstration of tools and training for partners as well as consulting services. The results of this activity are the application of modern shrimp paste processing machines to increase production capacity, the use of simple opening for mediumsized, packaging of various sizes of shrimp paste products with safe, aesthetic and ergonomic packaging materials.
\end{abstract}

Keywords: Technological innovation, Puger shrimp paste 
INTEGRITAS : Jurnal Pengabdian

Vol 5 No 1 Juli 2021

ISSN $2580-7978$ (cetak) ISSN 2615 - 0794 (online)

\section{PENDAHULUAN}

Pembuatan terasi telah dikenal cukup lama di Indonesia dengan udang laut sebagai bahan dasarnya. Jenis udang laut yang digunakan sebagai bahan dasar untuk pembuatan terasi adalah udang Rebon. Terasi merupakan kuliner khas Indonesia khususnya daerah-daerah pesisir. Rebon merupakan nama jenis udang laut kecil yang digunakan sebagai bahan dasar pembuatan terasi Puger. Udang ini memiliki nutrisi yang sangat bermanfaat bagi kesehatan dengan kandungan yang cukup tinggi terutama kandungan omega tiga, protein hewani, zat kitin dan iodium (Lukman, 2013).

Udang Rebon merupakan komoditas laut yang banyak ditemukan dalam jumlah yang melimpah di Perairan Jember selatan. Kecamatan Puger khususnya Desa Puger Kulon sebagai pelabuhan perikanan di Kabupaten Jember merupakan daerah penghasil ikan laut. Berbagai jenis ikan laut yang dihasilkan sebagian dipasarkan dalam bentuk segar, dan tidak sedikit pula yang diolah menjadi berbagai produk olahan ikan seperti ikan kering, terasi Puger, kerupuk ikan dan pindang. Pusat penghasil terasi Puger di Kabupaten Jember adalah di Kecamatan Puger tepatnya di Desa Puger Kulon (Sugiartono dan Ambarkahi, 2014).

Industri kecil terasi Puger yang terpusat di Desa Puger Kulon kurang lebih berjumlah 40 unit usaha. Usaha ini dilakukan secara turun temurun baik metode pembuatan maupun proses pengemasan terasi Puger yang semuanya masih dilakukan secara sederhana dengan tenaga manusia (Farid, 2013).

Permintaan terasi Puger yang diproduksi oleh pengusaha terasi Puger Desa Puger Kulon tidak hanya datang dari pasar-pasar di Kabupaten Jember saja, tetapi juga datang dari beberapa pasar di luar Kabupaten Jember. Upaya pemenuhan permintaan terasi Puger terkendala dengan keterbatasan alat pengolah terasi yang selama ini masih menggunakan alat penumbuk sederhana sehingga produksi terasi Puger terlihat kurang higienis. Akibatnya, tampilan produk yang dihasilkan terkesan kurang higienis dan kurang menarik. Disamping itu, kendala keterbatasan alat, bentuk kemasan produk, dan sistem pemasaran yang dilakukan masih sangat 


\section{INTEGRITAS : Jurnal Pengabdian}

Vol 5 No 1 Juli 2021

ISSN 2580 - 7978 (cetak) ISSN 2615 - 0794 (online)

sederhana sehingga nilai jual produk tidak ada peningkatan signifikan dari tahun ke tahun (Anrosana dan Gemaputri, 2016).

Berdasarkan data dan fakta yang telah diuraikan, maka kegiatan pengabdian kepada masyarakat ini menawarkan suatu inovasi teknologi berupa penggunaan alat pengolah dan pengemas terasi modern yang dapat menghasilkan terasi puger dengan kuantitas lebih besar, kualitas yang baik, higienis dan aman dikonsumsi sehingga produk lebih cepat terjual dan dapat bersaing dengan terasi yang dihasilkan dari daerah lain di Jawa Timur.

\section{METODE}

Kegiatan pengabdian kepada masyarakat yang telah dilaksanakan ini dapat menjadi solusi bagi permasalahan yang dihadapi mitra di Desa Puger Kulon Kecamatan Puger. Beberapa metode pendekatan yang dilakukan untuk menyelesaikan persoalan yang dihadapi pengusaha terasi Puger antara lain:

1. Pengenalan, bimbingan dan pelatihan secara intensif tentang operasional mesin pengolah terasi modern, serta hal-hal lain yang menunjang keberhasilan proses pengolahan terasi, seperti kemampuan kerja alat terkait dengan waktu dan kapasitas tampungnya, faktor-faktor yang mempengaruhi kualitas terasi puger, komposisi kandungan gizi, serta kapasitas dan biaya operasional penggunaan alat pengolah terasi.

2. Memberikan bimbingan dan pelatihan secara intensif tentang pengemasan produk serta manajemen bisnis dan pemasaran terasi puger.

Agar inovasi teknologi dan bisnis pada kegiatan ini dapat tersampaikan dan diterima dengan baik, maka diperlukan suatu strategi dalam impelementasinya, berupa kejelasan komunikasi, yaitu dengan memperhatikan pesan (message) yang disampaikan dan media/saluran komunikasi (channel) yang digunakan. Pesan yang disampaikan dilakukan dengan menggunakan bahasa yang mudah dimengerti dan dipahami oleh mitra, serta memperhatikan waktu dan tempat yang tepat saat menyampaikan pesan. Saluran komunikasi yang digunakan harus terbebas dari gangguan, baik gangguan teknis ataupun gangguan sosial budaya. 


\section{HASIL DAN PEMBAHASAN}

Hasil kegiatan pengabdian kepada masyarakat yang telah dilakukan di sentra agroindustri pengolahan terasi Desa Pugerkulon Kecamatan Puger Kabupaten Jember, secara garis besar dapat dilihat pada Tabel 1.

Tabel 1. Hasil kegiatan pengabdian kepada masyarakat di sentra agroindustri terasi Puger Desa Pugerkulon Kecamatan Puger Kabupaten Jember

\begin{tabular}{|c|c|c|}
\hline No. & Item Kegiatan & Hasil \\
\hline 1 & $\begin{array}{l}\text { Pengenalan inovasi mesin pengolah terasi } \\
\text { modern }\end{array}$ & $\begin{array}{lcr}\text { Penyerahan } & 3 & \text { mesin } \\
\text { pengolah terasi } & \text { modern } \\
\text { berbahan stainlessteel } & \text { kepada } \\
\text { Mitra } & \end{array}$ \\
\hline 2 & $\begin{array}{l}\text { Pengurusan ijin usaha dan ijin edar produk } \\
\text { bagi Mitra kegiatan PkM }\end{array}$ & 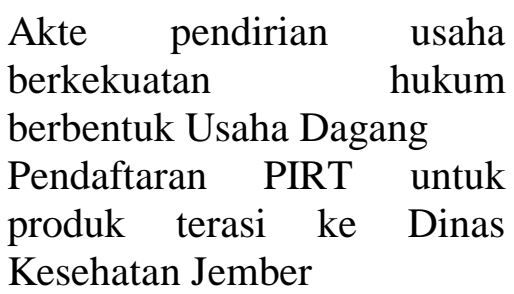 \\
\hline 3 & $\begin{array}{l}\text { Pendampingan manajemen usaha bagi } \\
\text { Mitra }\end{array}$ & $\begin{array}{l}\text { Pembukuan sederhana untuk } \\
\text { UMKM, pembuatan katalog } \\
\text { produk dan media promosi }\end{array}$ \\
\hline 4 & Pendampingan uji komposisi nutrisi terasi & $\begin{array}{lrr}\text { Surat Keterangan Komposisi } \\
\text { Nutrisi } & \text { Terasi dan } & \text { Bebas } \\
\text { Bahan } & \text { Berbahaya } & \text { dari }\end{array}$ \\
\hline & & 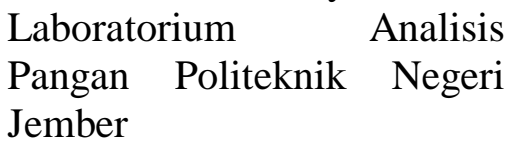 \\
\hline 5 & Pendampingan pengemasan produk & $\begin{array}{l}\text { Kemasan produk kedap udara } \\
\text { dan pemberian label produk }\end{array}$ \\
\hline
\end{tabular}

Survey lokasi bahan baku utama dan bahan baku penunjang dilakukan selama dua hari berdasarkan kelayakan wilayah dan kelimpahan bahan baku sehingga target dari kegiatan ini dapat tercapai yaitu diperolehnya bahan baku utama dan bahan baku penunjang yang berkualitas, harga terjangkau dan menemukan supplier tetap bahan baku langsung dari sumbernya. Hasil survey yang dilakukan menunjukkan bahwa Desa Pugerkulon merupakan sumber bahan baku utama yang melimpah, akan tetapi Desa Sumberejo dapat pula dijadikan 


\section{INTEGRITAS : Jurnal Pengabdian}

Vol 5 No 1 Juli 2021

ISSN 2580 - 7978 (cetak) ISSN 2615 - 0794 (online)

alternatif sumber bahan baku utama karena kualitas udang rebon di desa ini juga sangat baik akan tetapi tidak sebanyak di Desa Pugerkulon.
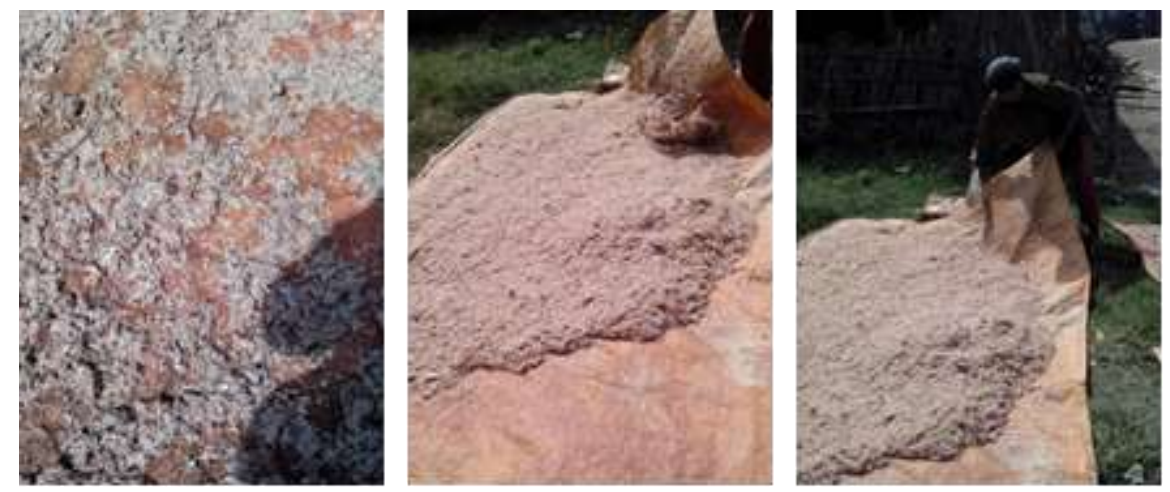

Gambar 1. Bahan baku utama udang Rebon dari sumber bahan baku wilayah pesisir Puger

Pendampingan pengurusan ijin usaha yang lakukan adalah mendaftarkan bentuk usaha dan ijin usaha yang akan dilakukan ke instansi terkait yaitu Pengadilan Negeri Kabupaten Jember melalui Notaris. Proses ini telah dilakukan dan hasil berupa Akte Pendirian Usaha Dagang Mina Pangan (salah satu mitra). Pendampingan ijin edar produk berupa pendaftaran PIRT ke Dinas Kesehatan Kabupaten Jember.

Pendampingan manajemen usaha yang dilakukan pada kegiatan pengabdian masyarakat meliputi pendampingan business plan, penentuan harga jual produk, analisis usaha, pembukuan sederhana untuk UMKM, strategi pemasaran serta pola kemitraan usaha yang saling menguntungkan.

Penerapan inovasi teknologi alat pengolah terasi, pengemasan produk dan uji komposisi nutrisi dilakukan dalam kegiatan ini untuk meningkatkan kapasitas produksi dan upaya peningkatan volume penjualan. Adapun gambaran singkat bentuk penerapannya dapat dilihat pada Gambar 2 dan Gambar 3.
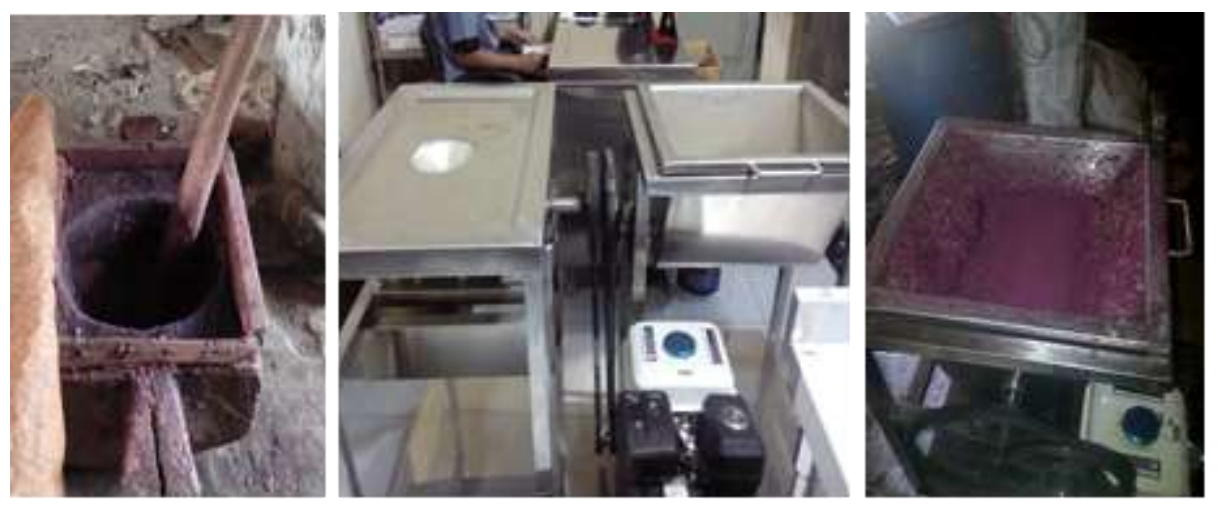
Gambar 2. Inovasi teknologi alat pengolah terasi
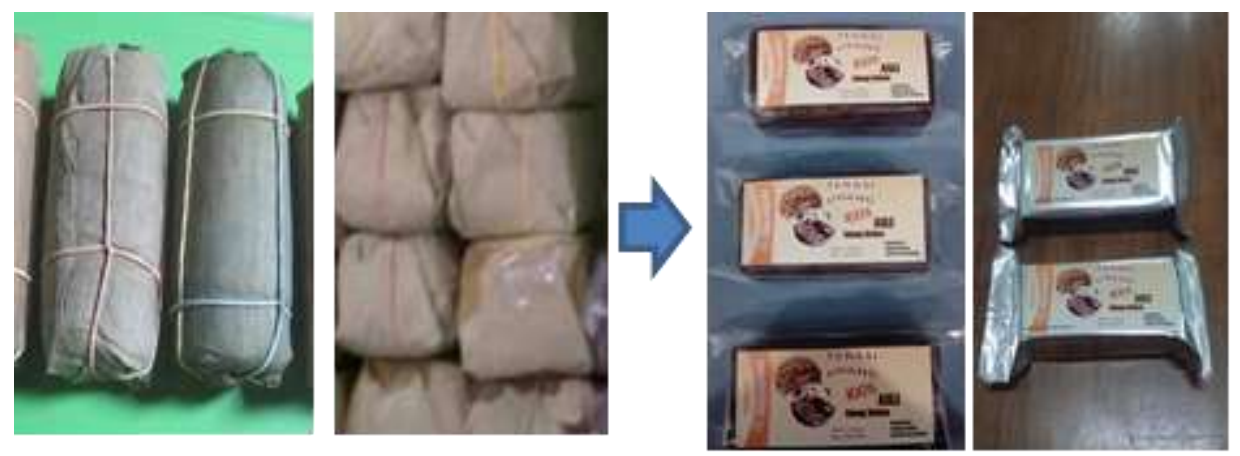

Gambar 3. Inovasi kemasan terasi Puger dengan kemasan kedap udara, modern dan higienis

Pendampingan kualitas SDM dilakukan untuk meningkatkan perform tenaga kerja yang dimiliki pengusaha agroindustri, meliputi pendampingan keterampilan penggunaan mesin pengolah terasi, pendampingan pemahaman selera konsumen tentang produk terasi, pendampingan cara pelayanan terhadap pelanggan, pendampingan kesehatan dan keselamatan kerja, dan pendampingan sanitasi lingkungan serta higienitas produk.

Promosi produk yang telah dilakukan adalah dengan menyebarkan brosur, booklet dan melalui sosial media berupa Instagram, Whatsapp dan Facebook. Penyebaran brosur produk, booklet dan pemberian kartu nama dilakukan pada saat melakukan penjualan di acara/event pameran

Tahapan selanjutnya setelah pelaksanaan kegiatan pelatihan adalah evaluasi hasil kegiatan. Evaluasi dilakukan untuk menilai seberapa jauh keberhasilan dari kegiatan pengabdian kepada masyarakat yang dilakukan. Indikator-indikator yang digunakan dalam mengevaluasi kegiatan pengabdian kepada masyarakat ini adalah sebagai berikut :

1. Tingkat responsibilitas mitra kegiatan terhadap inovasi yang ditawarkan dalam kegiatan ini

2. Daya serap mitra kegiatan untuk mengadopsi dan mendifusikan inovasi yang telah dipelajari 


\section{INTEGRITAS : Jurnal Pengabdian}

Vol 5 No 1 Juli 2021

ISSN 2580 - 7978 (cetak) ISSN 2615 - 0794 (online)

3. Kemampuan dan kemauan mitra mengaplikasikan inovasi teknologi yang telah dipelajari

\section{KESIMPULAN}

Kegiatan pengabdian kepada masyarakat ini menunjukkan dampak yang positif dalam merubah pola produksi terasi Puger kearah yang lebih baik dan modern, membuka wawasan mitra kegiatan akan pentingnya mengemas produk dengan bahan kemasan yang aman, menarik dan berbagai variasi bentuk serta ukuran yang dapat meningkatkan nilai jual produk. Penggunaan media cetak dan elektronik dalam promosi dan pemasaran dapat mempercepat penyerapan produk dan memperluas jangkauan pasar.

\section{UCAPAN TERIMA KASIH}

Terima kasih disampaikan kepada Direktur dan Pusat Penelitian dan Pengabdian Kepada Masyarakat Politeknik Negeri Jember, terima kasih juga disampaikan kepada Kementerian Riset Teknologi dan Pendidikan Tinggi yang telah mendanai kegiatan pengabdian kepada masyarakat ini melalui Program Calon Perusahaan Pemula Berbasis Teknologi dari Perguruan Tinggi.

\section{DAFTAR PUSTAKA}

Sugiartono, E., dan Ambarkahi, R. P. Y. (2014). Identifikasi Indikator Kinerja dan Persepsi Pelanggan sebagai Upaya untuk Meningkatkan Mutu Layanan dan Produk Unggulan Terasi Puger. Laporan Penelitian Unggulan Perguruan Tinggi.

Farid, L. (2013). Implementasi Task Tree Analysis dan Fishbone Diagram dalam menentukan Gambaran Produk Terasi Berkualitas. Skripsi. Jember: Politeknik Negeri Jember.

Anrosana, I. A., dan Gemaputri, A. A. (2016). Kelompok Usaha Terasi Puger. Jurnal DINAMIKA, 1 (1), 39-42.

Lukman, A. (2013). Pembuatan Terasi. Artikel. Jakarta: Majalah Sekar Edisi 115. 